\title{
The House of Dewi Andini: Integrated Guidance Model for Marriage Prevention Efforts
}

\author{
Riris Arinty \\ Department of Guidance and Counseling \\ State University of Malang, Indonesia \\ ririsarintyabkum@gmail.com \\ Daniati Rohmah \\ Department of Educational Geography \\ State University of Malang, Indonesia \\ rohmahdaniati@gmail.com
}

Rosilatus Sa'dila

Department of Educational Chemistry

State University of Malang, Indonesia rosilatus.sadila@gmail.com

\author{
Ahmad Padhlillah \\ Department of Educational Automotive Engineering \\ State University of Malang, Indonesia \\ ahmadfadlillah15@gmail.com \\ Melly Maulidah Fitriani \\ Department of Educational Indonesian Language \\ State University of Malang, Indonesia \\ fitrianimaulidah@gmail.com \\ Muslihati \\ Department of Guidance and Counseling \\ State University of Malang, Indonesia \\ muslihati.fip@um.ac.id
}

\begin{abstract}
Wajak sub-district has been ranked first in the case of early marriage in Malang Regency Indonesia in the period 2017. Early marriage more negative impact for adolescent couple. It is reviewed in terms of health, psychological, economic, and social. This program aims to provide education and information about early marriage along with the negative impact, maturity of marriage age, and career planning so that it can menajadi prevention program to practice early marriage in Wajak Village, Malang Regency. This program is an educational activity with three forms of activities that include: classical counseling, youth counseling, and biblioeducation. Classical guidance activities are conducted with five methods, including: expository method, group discussion, educational video, simulation game, and out bond. The result of this activity is the change of mindset of adolescent of Wajak Village about early marriage and motivation improvement for career planning after getting education and information with classical guidance strategy. The success of this program is demonstrated by the increasing knowledge of adolescents in planning their career through data analysis and interview results before and after the program delivery.
\end{abstract}

Keywords: the house of dewi andini, information, early marriage, prevention

\section{INTRODUCTION}

Early marriage rate in Malang Regency Indonesia is still high. This is the main concern of Malang regency government. Recorded from data of Population and Family Planning (DPPKB) Malang Regency in 2017, there are 4,272 cases of early marriage that occurred in Malang Regency. Of the 33 districts in Malang Regency, Wajak is the region with the highest early marriage rate in Malang regency. Based on the marriage data of Kantor Urusan Agama (KUA) Wajak Village Wajak District of Malang Regency, from 13 villages in Wajak District the highest level of early marriage is found in Wajak Village with the percentage of $16.14 \%$.

Various cases of early marriage have several factors, including educational factors, technological factors, economic factors, and cultural factors. The low education of parents and adolescents encourages early marriage. According to Kartika [1], states that education has an important role in providing insight into risky sexual behavior and adolescent reproductive health. With low educational conditions rather than being a burden on the family, in the end parents encourage their children to get married soon. Next on technology factor. technological developments can also trigger the occurrence of early marriage. Technological developments will have a negative impact if there is no supervision in their use. One of the negative effects of technological development is access to pornographic content from cyberspace [1].

This can lead to changes in teenage sexual behavior that encourages him to make promiscuity and end up at an early marriage. Wajak District residents number 81.824 people with the majority of the population working as farmers, traders, craftsmen and many who become Indonesian Workers (TKI) abroad such as Saudi Arabia, Malaysia, Hong Kong, Taiwan, and many more. Most of the workers are women. The level of education is still a lot that has not reached the level of college. Educational background and economic level of the population is the factor of the occurrence of early marriage which is one way to ease the burden of the family economy. Based on the results of interviews PKK cadres on April 15, 2018, it can be concluded that the habits of people who have become a culture is very influential on the occurrence of early marriage practices. This is included in the socio-cultural factor of avoiding the assumption of the community as an old maid. In terms of religion, marriage is also considered as a way to avoid adultery [1].

Early marriage is more negative for children. Marriage that goes without mental preparedness will end in divorce. In addition, vulnerable also occurrence of Domestic Violence (KDRT) with women as victims. Girls who marry at an early age will lose their time in science because after marriage most of them will drop out of school. In terms of health, early marriage will be 
at greater risk of death during childbirth in children who have not matured reproductive organs. So far, Malang Regency government has cooperated with the Regional Device Organization (OPD) including the Office of Population and Family Planning (DPPKB) and Health Office (DHO).

Both play a role in accordance with their duties in tackling cases of early marriage. The role is realized in the form of socialization conducted on 33 districts in Malang Regency ([2], [3], [6]). DPPKB, for example, has developed a Teens Generation Youth (TE) Information and Counseling Center (PIK). The government continues to make efforts to control cases of early marriage through volunteers but there are some things that become weaknesses for PIK Insan GenRe so until 2017 early marriage figures are still quite large. Based on interviews conducted to one of the Wajak Village teenagers on May 20, 2018, it was stated that the socialization of early marriage by PIK Insan Genre is only done and centered on one of the schools in Wajak Village. Though there are five schools both Junior High Schools / Islamic Junior High School and Senior High School / MA which is located in Wajak Village. Thus, socialization efforts in the effort to prevent early marriage is still not comprehensive to Wajak Village teenagers in particular.

Based on the above explanation, necessary precautions to overcome the problem of early marriage. Socialization about the negative impact of early marriage is not enough if not done with periodic intensity and closer to the community. Therefore, PKM-Community Service (PKM-M) provides an alternative solution to educate Wajak Village Village Wajak youth through Griya Dewi Andini. Griya Dewi Andini is a space that provides education and information as an effort to prevent early marriage with integrated guidance model for teenagers in Wajak Village, Wajak District, Malang Regency. The program activities include classical guidance, biblioeducation, and youth counseling. The activities in cooperation with the PKK team are expected to be a sustainable effort after the dedication of the activities ends.

\section{METHODS}

In the implementation of Griya Dewi Andini Program, the PKMM team initiated it by developing training programs for Wajak Village teenagers. Form of socialization and training using a strategy of classical guidance. Classical guidance is a service performed in class settings in the form of scheduled face-to-face and on a regular basis [4]. In addition, the methods used in classical guidance to deliver materials include: expository techniques, educational videos, group discussions, and games.

Training of adolescents with this strategy of classical guidance was held on 20 and 27 May 2018, 3 and 4 July 2018 with participants as many as 35 teenagers Wajak Malang Regency. On May 20,27 and 3 June 2018, the event starts at 4:00 pm and ends at $5: 30 \mathrm{pm}$ which is followed by an open activity. This is because the implementation of this activity coincides with the month of Ramadan. On July 4, 2018, the event started at 09.00 and ended at 12.00. The training was conducted in four stages of face-to-face activities. The first activity using expository methods and educational videos. The second activity is using expository and group discussions. The third activity is by using game simulation method.

1. First Activity: Expository and Video Education Method

The expository or also called the lecture method is an explanation by a speaker to a group of listeners [5]. The purpose of this method is to convey much information and material with limited time to the trainees. The expository method has advantages and disadvantages. The advantage of this method is that it can serve many people, it does not take much time so it is more efficient, and does not require too many facilities for its implementation.

The weakness of the expository method is that it tends to center on the speaker, is less interactive, and requires good speaking skills. In the use of this method, the presenters collaborate with other methods. The expository method is used by the presenters because it can be used to describe the initial material on the meaning of early marriage and its negative impact. The presenters are from either the PKMM team itself or from the pre-specified speakers by the team. In the implementation, also conducted question and answer to make participants more active and not tend to center on the speaker.

The educational video method is a video playback that has an educational value about the negative impact of early marriage and maturity of marriage age. The purpose of this method is to enable trainees to be more aware of the negative impact of early marriage in terms of health, psychological, economic, and social. Educational videos attract more participants. This is because through video viewing, participants can receive information and materials in audio-visual. In the next stage, to know the understanding of the participants then do the reflection of the video content. This reflection is done verbally by providing the questions that the trainee answers. At the time of reflection, the trainee gets an opportunity to express his opinion on the things that are in the educational video show.

\section{Second Activity: Expository Method and Group Discussion}

The expository method as a technique of information is chosen because it can be used to describe the material about the maturity of marriage age and the ideal age of marriage in terms of health, psychological, economic, and social. The use of this expository method has a disadvantage that one of them is centered on the speaker and less interactive. Therefore, group discussion methods are used to enable participants to be more involved and active in the training.

Group discussion is an activity to clarify an issue or material that has been discussed by three or more people [5]. The group discussion in this activity also aims to summarize the opinions of participants in a group. In practice, large groups are divided into small groups. After that, each group gets a task to discuss and 
summarize the material that has been delivered by the speaker. Furthermore, each group through its representatives makes a presentation of the results of group discussions in front of other groups.

\section{Third Activity: Simulation Game Method}

Games in general can be interpreted as a fun activity, competitive, and spirited. This game is also the most important part in building group dynamics. According to Shertzer and Stone [5], states that group dynamics are forces in the interaction between group members as the activity progresses to achieve group goals. This game method can make participants more passionate in following the training activities. This method makes the participants more active and not just centered on the speaker.

In practice, material can be included in every game. Here are games that can be used in adolescent training: simulation games, both structured and unstructured game play, and traditional games. At this third meeting, the game used is game simulation.

This simulation game method can be used for selfunderstanding material. The simulation game is simulation with some message cards containing questions. Any questions that can be answered will earn points and can be exchanged for prizes as a reward form of the participants. The questions are about potential self-understanding of talent and interest.

\section{RESULTS}

The number of early marriage practices in Wajak Village, Malang Regency has several factors. According to Kartika [1], factors causing the occurrence of early marriage practices include educational, economic, technological, socio-cultural, and religious. These factors are also the cause of early marriage practices in Wajak Village. Although not all of the factors mentioned are experienced by every adolescent couple. Based on interviews conducted to the PKK cadre chairman on April 15, 2018, early marriage in Wajak Village Malang Regency is mostly done by adolescents with female gender. It is more likely due to socio-cultural factors in Wajak society. Habits are done has become a culture of society so that parents will marry off their daughters who are not in school.

Judging from several aspects, early marriage caused many negative impacts. Some of these aspects include: health, psychological, social, economic [1]. Negative impacts can be experienced by both women and men, but women are more dominantly affected by these negative impacts. Basically, early marriage poses a risk to health because of the reproductive organs that are not ready. Furthermore, from the psychological side of adolescents who still can not manage emotionally will affect the interpersonal relations of their partners so that the events of domestic violence, divorce, and others are possible. Teenagers who do not have the competence will also have problems with the family economy.

Based on the above exposure required preventive measures as an effort to prevent cases of early marriage in Wajak Village. Preparation of the program in cooperation with the team of PKK Village Movement Wajak can be one way that can be done. The program is carried out regularly with the form of training and is educational. The program is then called Griya Dewi Andini which is designed as an educative teen community to get information and education about early marriage, negative impact of early marriage, and maturity of marriage age. In it also provides education about self-understanding and career planning for Wajak Village teenagers. Thus, early marriage prevention efforts can be implemented through the program Griya Dewi Andini.

Implementation of training with this classical guidance strategy has been well implemented. Participants who are young people of Wajak Village give high enthusiasm. Therefore, it can be concluded that this program received a positive response both from the government of Wajak Village and from the target or participants.

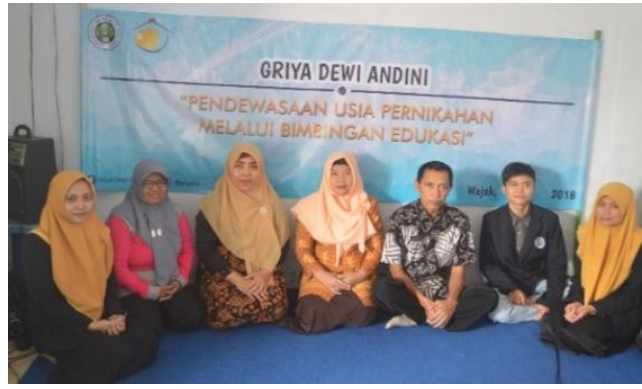

Picture 1

Opening Activity of Griya Dewi Andini

This program begins with the opening and inauguration of Griya Dewi Andini attended by Head of Wajak Village, PKK Cadre, PKM Assistant Lecturer, and PKM team (Picture 1). Implementation of this activity aims to provide socialization to PKK cadres about the education and information programs as prevention of early marriage. The village head gives support to the implementation of this program by allowing the PKM team to carry out activities in the village hall.

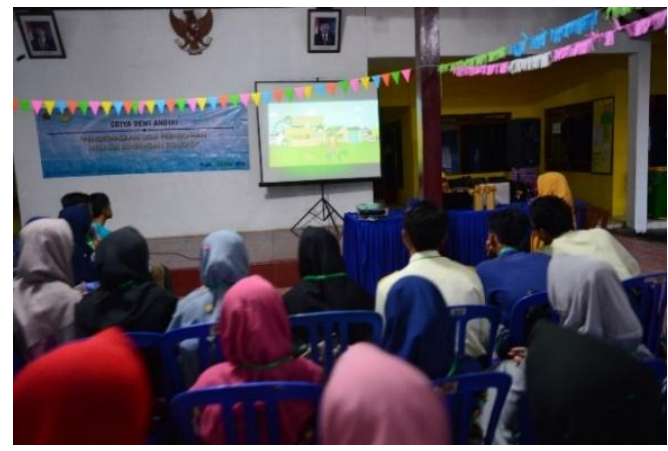

Picture 2

Classical Guidance Activities Day One

Training with a classical guidance strategy begins with a symbolization of pin pinning by village representative to the participants (Picture 2). The 
activity continued with the presentation of material about early marriage and its negative impact through expository method and educational video. Participants are very enthusiastic about giving their opinions when asked about this material (Picture 3).

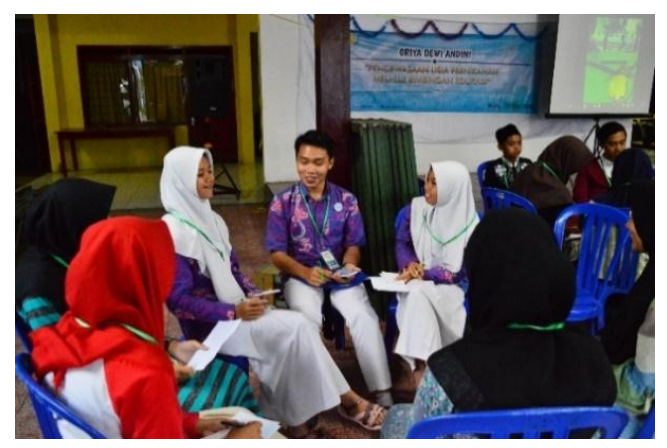

Picture 3

Second Class Guidance Activities

On the second day, the activity of classical guidance with maturity material of marriage age. The methods used are eksopsitori and group discussion. Participants are very active and eager to follow the activities from beginning to end (Figure 4).

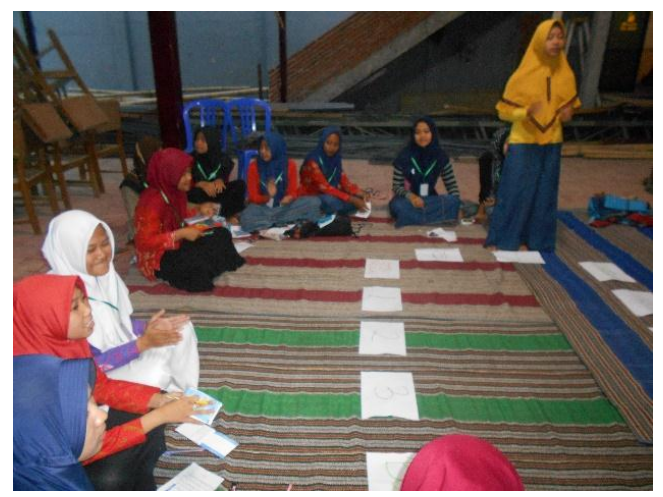

Picture 4

Third Day Guidance Activities

On the third day, classical guidance activities with self-understanding materials were welcomed by the participants. The method used is simulation game in the form of some simulation. Participants are asked to count as the initial activity of small group formation. Each group competes for points to get questions. The group with the most points will get the prize as a form of appreciation.

On the fourth day, classical guidance activities with career information materials were greeted with high enthusiasm by the participants. The method used is outbound in form of game between groups (Picture 5 ). Outbound method is one type of game method that can be used in a group. Career information as the main material can be provided by incorporating the material into a particular game. All methods used are in order to achieve the purpose of providing education and information as an effort to prevent early marriage for Wajak Village teenagers.

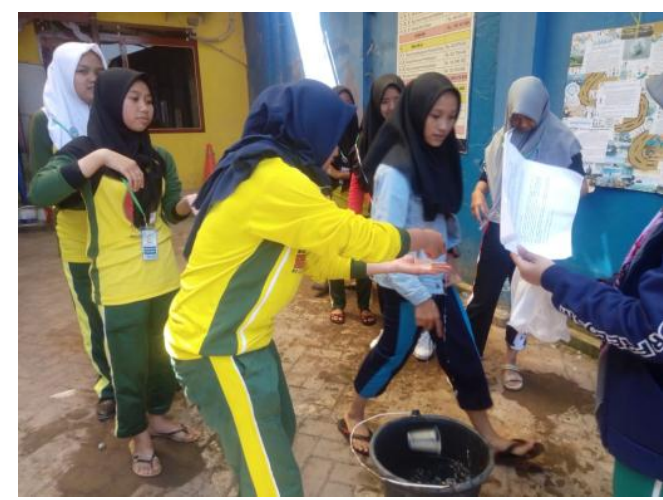

Picture 5

Fourth Day Guidance Activities

\section{DISCUSSION}

The number of early marriage practices in Wajak Village, Malang Regency has several factors. According to Kartika [1], factors causing the occurrence of early marriage practices include educational, economic, technological, socio-cultural, and religious. These factors are also the cause of early marriage practices in Wajak Village. Although not all of the factors mentioned are experienced by every adolescent couple. Based on interviews conducted to the PKK cadre chairman on April 15, 2018, early marriage in Wajak Village Malang Regency is mostly done by adolescents with female gender. It is more likely due to socio-cultural factors in Wajak society. Habits are done has become a culture of society so that parents will marry off their daughters who are not in school.

Judging from several aspects, early marriage caused many negative impacts. Some of these aspects include: health, psychological, social, economic [1]. Negative impacts can be experienced by both women and men, but women are more dominantly affected by these negative impacts. Basically, early marriage poses a risk to health because of the reproductive organs that are not ready. Furthermore, from the psychological side of adolescents who still can not manage emotionally will affect the interpersonal relations of their partners so that the events of domestic violence, divorce, and others are possible. Teenagers who do not have the competence will also have problems with the family economy.

\section{CONCLUSION}

Griya Dewi Andini is an education and information program as an effort to prevent early marriage in Wajak Village, Malang Regency. This program is implemented through training with classical guidance strategies with different materials each time the meeting. Education on early marriage and career planning for teenagers has changed their mindset.

\section{ACKNOWLEDGMENT}

The preparation of this scientific article is well resolved to various related parties, so praise to Allah SWT over the abundance of His grace and guidance so that the completion of this scientific article. Acknowledgments of the authors convey to the 
Ministry of Research, Technology, and Higher Education for the support and assistance of funding so that this PKM-M program can be implemented.

Furthermore, the Rector of State University of Malang, the Reasoning Team of State University of Malang, and the lecturer of PKM-M for the support given and the guidance. Head of Wajak Village and PKK Team of Wajak Village that has provided support so that PKMM program can be done well.

\section{REFERENCES}

[1] Gunawan, I. 2017. Landasan Dasar Pendidikan. Malang: Universitas Negeri Malang, UM Press.

[2] Kartika R.. 2014. Dampak Perkawinan Anak di Indonesia. Jurnal Studi Pemuda, 3(1). Retrieved January 12, 2018, from https://journal.ugm.ac.id/jurnal pemuda/article/viewFile/32033/19357.

[3] Malangtimes.com. 2017. Pernikahan Dini di Wajak Tertinggi Se-Kabupaten Malang, Dinas Pengendalian Penduduk dan KB Tingkatkan PIK GenRe. Retrieved January 12, 2018, from http://www.malangtimes.com /baca/19552/20170721/095042/pernikahan-dini-diwajak-tertinggi-sekabupaten-malang-dinaspengendalian-penduduk-dan-kb-tingkatkan-pik-genre.

[4] Malangtimes.com. 2017. Pernikahan Dini Masih Tinggi, Kabupaten Malang Genjot Jumlah PIK Insan GenRe. Retrieved January 12, 2018, from http://www.malangtimes.com/baca/17685/20170323/15 0954/pernikahan-dini-masih-tinggi-kabupaten-malanggenjot-jumlah-pik-insan-genre.

[5] Permendikbud Nomor 111 Tahun 2014 tentang Bimbingan dan Konseling pada Pendidikan Dasar dan Pendidikan Menengah. 2015. Jakarta: Ministry of Education and Culture.

[6] Romlah, T. 2013. Teori dan Praktik Bimbingan Kelompok. Malang: State University of Malang. 